\title{
Covid-19 Pandemi Sürecinde 14 Kuralın Türk İşaret Dili Çevirileri Üzerine Bir İnceleme
}

\section{A Study on the use of the 14 Rules of Turkish Sign Language Interpreting during the Covid-19 Pandemic}

Araştırma / Research

\section{A. Zeynep ORAL*, A. Şirin OKYAYUZ**}

*Doç. Dr. Hacettepe Üniversitesi, Edebiyat Fakültesi, Mütercim Tercümanlık Bölümü, Fransızca Mütercim Tercümanlık Anabilim Dalı, zen@hacettepe.edu.tr, ORCID ID: orcid.org/0000-0001-6378-5464

**Doç. Dr. Hacettepe Üniversitesi, Edebiyat Fakültesi, Mütercim Tercümanlık Bölümü, İngilizce Mütercim Tercümanlık Anabilim Dalı, yener@bilkent.edu.tr, ORCID ID: orcid.org/0000-0001-7512-2764

\section{ÖZET}

COVID-19 virüsü kamu sağlığını tehdit etmektedir; dolayısıyla tüm toplumun bilinçli bir şekilde hareket etmesi de önem kazanmaktadır. Bu bilinç ise ancak doğru bilgilendirme ile gerçekleşebilmektedir. İçinde olduğumuz gibi dönemlerde toplumda her türlü platforma erişebilen bireylere bile doğru ve hızlı bilgi iletilmesi zorludur. Bilginin doğru ve hızlı yayılımı için atılması gereken adımların önünde ise bazı engellerin olduğu yadsınamaz. Sağır topluluk, çalışmada irdeleneceği üzere, toplumun diğer üyelerinden bazılarından farklı olarak pandemi sürecinde güvenilir kaynaklarda yayımlanan bilgilere erişimde ek zorluklar yaşamıştır. Çalışmada Sağır topluluğun Türkiye'de en temel pandemi önlemi olarak görülen 14 Kurala erişimindeki farklı çevirileri, çevirilerin amaçları doğrultusunda incelenmektedir. Çalışmanın ilk bölümünde engelsiz erişim bağlamında Sağır topluluğun gerçekleri paylaşılmaktadır. İkinci bölümde ise ilk bölümdeki bilgiler ışığında 14 Kural ve Türk İşaret Diline (TiD) iki çevirisi irdelenmektedir. Çalışmanın sonuç bölümünde ise engelli bireyler için bilgilendirmenin önemi vurgulanmakta ve incelemeden elde edilen veriler çerçevesinde özellikle de pandemi gibi kriz süreçlerinde farklı platformlardan ve farklı yaklaşımlarla doğru çevirilerin sunulmasının önemi üzerinde durulmaktadır.

Anahtar Sözcükler: Koronavirüs, 14 Kural, bilgiye erişim hakkı, sağlık çevirmenliği, yazılı metinden sözlü çeviri, yanmetin 


\section{ABSTRACT}

The COVID-19 virus is a threat to public health; thus it becomes vital for society to be informed to combat this threat. The information provided has to be correct for society at large to be aware of the threat. In periods such as the one we are living through, it is difficult to convey accurate and fast information to even those individuals who enjoy access to different platforms in society. It is clear that there are obstacles to the steps to be taken for the correct and fast dissemination of information. Furthermore, as will be discussed in the study, unlike the other members of society, the Deaf community experienced additional difficulties in accessing information obtained from reliable sources during the pandemic. The study provides an analysis of the different on sight translations/interpretations of the Coronavirus 14 Rules into Turkish Sign Language with emphasis on the skopos of the translations. The first part of the study entails the realities difficulty of access of the Deaf community. The second part, in the light of the information shared initially, provides an analysis of the two different Turkish sign language target texts of the 14 Rules. Within the framework of the data obtained from the study, the conclusion emphasizes the vitality of informing the disabled and underlines the importance of providing correct information through different approaches and differing platforms.

Keywords: Coronavirus, 14 Rules, right to information, interpreting for health services, sight translation, paratext

\section{Giriş}

COVID-19 virüsü dünyayı hazırlıksız yakalamış ve bu süreçte, özellikle de pandeminin hızla yayıldığı ilk zamanlarda dezenformasyon ve yanlış bilgi dağılımı yaşanmıştır. Kimi zaman insanlar birbirlerinden, çevrimiçi ortamlardan ve hatta basından yanlış bilgi edinmiştir. Dünya çapında panik yaşandığı bir dönemde bu yanlış bilgi yayılımı ya da eksik bilgi edinilmesi paniğin körüklenmesine neden olmuştur. Bu süreçte yanlış bilgi yayılımını önlemek ve doğru bilgiyi paylaşmak Dünya Sağlık Örgütü’nün (DSÖ-WHO) ana uğraşlarından biri hâline gelmiştir. Örgüt internet sitesinin ana sayfasındaki kampanyalar sekmesi altında (bkz. WHO 2020- Home/Campaigns/Connecting the world to combat coronavirus/How to report misinformation online) Koronavirüsle mücadele ile ilgili olarak dezenformasyonun bildirilmesi için vatandaşları Facebook, Youtube, Instagram, Twitter, TikTok, WhatsApp, LinkedIn, Viber gibi ortamlara yöneltmiştir. Örgüt, aynı sayfada yaptığı açıklamada da COVID-19 pandemisi ile başa çıkmaya çalıştığımız bu dönemde virüsle ilgili bilgi yayılımının bir sorun olduğunu, yayımlanan ve yayılan bazı bilgilerin eksik ve yanlış ve potansiyel olarak tehlikeli olduğunu, bu yanlış bilgi hızla ve geniş çevrelere yayıldıkça da insanların güvenilir kaynaklardan doğru bilgiyi saptamalarının zorlaştığını iletmiştir.

Dünyanın her yerinde olduğu gibi Türkiye'de de COVID-19'a ilişkin bilgi hızla yayılmakta ve özellikle de doğru ve güvenilir bilgiye erişim bir sorun olabilmektedir. T.C. Sağlık Bakanlığı'nın T.C. Sağlık Bakanlığı COVID-19 Bilgilendirme Sayfası (2020) adıyla yayımladığı ve her gün güncellediği internet sayfası doğru bilgilere erişim için güvenilir bir kaynak sunmak amacıyla hazırlanmıştır. COVID-19 sürecinde tüm toplumun sağlığını korumak için Koronavirüsün ne olduğu, nasıl yayıldığı, belirtilerinin ne olabileceği, hastalanan kişilerin ne yapması gerektiği, hasta sayısı ve insanların 
kendilerini korumak için ne yapmaları gerektiği gibi temel bilgilere herkesin erişimi olması önemlidir.

Sağlık Bakanlığı dışında belediyeler, üniversiteler, devlet daireleri ve insanların yoğun olarak bir arada bulunduğu yerlerdeki tüm yetkililer bilgilendirmeye gereken özeni göstermek için çaba harcamaktadır. Televizyonlarda pandemi hakkında programlar yayımlanmakta, uzmanlarla konular tartışılmakta, kamu spotları yayımlanmakta ve insanlar bilgilendirilmektedir. Kamu sağlığını tehdit eden bu pandemiye karşı bilinçli bir şekilde, doğru bilgilerden yola çıkarak mücadele verilmesi önemlidir.

Öte yandan, bilginin doğru ve hızlı yayılımı için atılması gereken adımların önünde bazı engellerin olduğu yadsınamaz. Her şeyden önce, bir ülkedeki tüm vatandaşlara erişilebilecek tek bir platformun tespit edilmesi olası değildir. Örneğin, Radyo ve Televizyon Üst Kurulu (RTÜK) Kamuoyu Yayın Araştırmaları ve Ölçme Dairesi tarafından 22 Aralık 2005 - 5 Ocak 2006 tarihleri arasında gerçekleştirilen Televizyon İzleme Eğilimleri Araştırmasında, hafta içi ve hafta sonu günlerde televizyon izleme düzeyi, hafta içi ve hafta sonu günlerde televizyon izleme saatleri, program türlerinin izlenme düzeyi, televizyon, gazete, radyo ve internet ile ilgili güven düzeyi saptanmış ve verilere göre televizyonun dahi Türkiye'nin her yerinde devamlı izlenmediği tespit edilmiştir (bkz. RTÜK, 2006). Aynı kurumun 2018 tarihli araştırmasında (bkz. RTÜK, 2018) Kamuoyu, Yayın Araştırmaları ve Ölçme Dairesi Başkanlığı günlük ortalama televizyon izleme sürelerini yıllar bazında karşılaştırmış ve 2006 yılından bu yana televizyon izleme sürelerinde belirgin bir azalma yaşandığını belirlemiştir. Araştırmaya katılanların \%69.2'si televizyona, \%62.3'ü yazılı basına, \%62.2'si radyoya, \%59.1'i internet üzerinden haber sitelerine ve \%53.7'si sosyal medyaya bir haber kaynağı olarak güvendiklerini belirtmişlerdir (RTÜK, 2018, s. 15).

Yazılı olarak sunulan kaynaklara erişimde de alıc kitlenin algı düzeyi (okuduğunu anlama düzeyi), okuryazar oranları, yazılı kaynaklara erişim kolaylığı, internet üzerinde yazılı kaynaklara erişim düzeyi ve benzeri unsurlar erişimi kısıtlayabilmektedir. Günümüz teknolojileri ile bile yaygın ve doğru bilgilendirme yapabilmek kolay değildir. Görsel-işitsel medyaya erişebilen ve Türkçe okuyup yazabilen kesitlere bilgiyi ulaştırmak için oldukça yoğun planlama, eşgüdüm ve çaba gerekirken, bu platformlara erişimi olmayan, olamayabilen veya kısmi erişimi olan kitlelerin bilgilendirilmesi de ayrı bir sorundur. Bu sorun yalnızca sözü edilen bilgiye erişimi kısıtlı olan kitleleri değil, bir pandemi ortamında Türkiye'de yaşayan herkesi ilgilendirmektedir.

Sağır topluluk, çalışmada irdeleneceği üzere, toplumun diğer üyelerinden bazılarından farklı olarak, pandemi sürecinde güvenilir kaynaklarda yayımlanan bilgilere erişimde ek zorluklar yaşamıştır. Çalışmada Sağır topluluğun Türkiye'de en temel pandemi önlemi olarak görülen 14 Kurala erişimindeki farklı çevirileri incelenmektir. 14 Kural T.C. Sağlık Bakanlığının sitesinde Covid-19 pandemi sürecinde bireylerin kendilerini korumaları için ortaya konmuş önlemlerdir ve bunlar metin olarak T.C. Sağıı Bakanlığı 'Kovid-19 Nedir' başlıklı resmi sekmesinde 'Korunma Yolları 
Nelerdir' altbaşlığı altında açıklanmıştır ${ }^{1}$. Çalışmanın ilk bölümünde engelsiz erişim bağlamında Sağır topluluğun gerçekleri ile ilgili bilgi paylaşılmaktadır. İkinci bölümde ise, ilk bölümdeki bilgiler ışığında, 14 Kural ve Türk İşaret Diline (TiD) iki çevirisi irdelenmektedir. Çalışmanın sonuç bölümünde ise engelli bireyler için bilgilendirmenin önemi vurgulanmaktadır.

\section{Sağır Topluluk ve Bilgiye Erişim}

Türkiye'de Sağır topluluğun (ve kimi işitme engelli bireyin) ana iletişim dili Türk İşaret Dilidir (TID); Türkçe konuşma diline ya erişimleri yoktur ya da bu erişim çok kısıtıdır. Dolayısıyla, görsel-işitsel medyada yapılan tüm bilgilendirme işaret diline çevrilmediği veya canlı altyazı (canlı altyazı açıklaması için bkz. Okyayuz 2019, ss. 76-81) ile sunulmadığı sürece, söz konusu bireyler görsel-işitsel ürünlerle bilgilendirme yapılan platformlardan bilgiye erişememektedirler.

Sağır topluluğun bilgiye erişmesinin önemi ve bu erişimi gerçekleştirmek için gereken açılımlar ve girişimler son yirmi yıldır sosyal ve politik gündemde olan bir konudur. Bu konunun gündemde olmasının en önemli nedenlerinden biri, dünyada, özellikle de güncel siyasi platformlarda yaşanan gelişmelerdir. Örneğin, Birleşmiş Milletler Engelli Hakları Sözleşmesi'nde (13 Aralık 2006) ve 15 Kasım 2010 tarihinde yürürlüğe giren Avrupa Engellilik Stratejisi gibi uluslararası belgelerde, engelli kişilerin de eşit fırsatlar çerçevesinde topluma ve ekonomiye katılım hakkı olması gerektiği açıkça belirtilmiştir. Yukarıda belirtilen ve alanda çok önemli bir gelişme olarak görülen Sözleşme, Birleşmiş Milletler Genel Kurulu'nun 13 Aralık 2006 tarihli ve A/RES/61/106 kararıyla kabul edilmiş ve 3 Mayıs 2008 tarihinde yürürlüğe girmiştir. Türkiye, Sözleşmeyi 30 Mart $2007^{2}$ tarihinde imzalamıştır. Başka örneklerde, 11 Kasım 2007'de yürürlüğe giren $A B$ Yönetmeliği (Directive 2007/65/EC) ve 10 Mart 2010'da yürürlüğe giren Görsel İşitsel Medya Hizmetleri Yönergesinde de medya erişimi konuları vurgulanmıştır. 2007 tarihli Yönetmeliğin 64'üncü maddesinde engelli kişilerin sosyal ve kültürel hayata katılımlarını sağlamak için erişilebilir medya hizmetleri sunulması konusu, yasal olarak zorunlu hâle getirilmiştir. Bu gibi uluslararası platformlardaki yasal girişimler nedeniyle de yerel medya sağlayıcıları değişiklikler yapmış, yenilikler getirmiştir. Örneğin, ülkemizde 2018 yılının son aylarında başlayan Sağırların, İşitme Engellilerin ve Görme Engellilerin Görsel-iş̧itsel Medya Hizmetlerine Erişiminin İyileştirilmesi Çalıştayı, 15 Ocak 2019'da yapılan bir toplantıda sunulan sonuç bildirisi ile tamamlanmıştır (bkz. RTÜK, 2019a). Ardından da Sağırların, İşitme ve Görme Engellilerin Yayın Hizmetlerine Erişiminin İyileştirilmesine İlişkin Usul ve Esaslar Hakkında Yönetmelik (bkz. RTÜK, 2019b) yayımlanmıştır. Bu gibi girişimlerin önemi yadsınamaz. Ancak, bu girişimlerin birer ilk adım olduğunu hatırlamak ve devamlılığına ve kaliteli erişimin sağlanmasının önemini vurgulamak gerekir.

Sağır ve işitme engelli kesimin erişimini sağlamak amacıyla görsel-işitsel ürünlerin işaret dili ile çevrilmesi önemlidir, ancak pandemi sürecinde tüm bilgiler

\footnotetext{
${ }^{1}$ (bkz. https://covid19.saglik.gov.tr/TR-66300/covid-19-nedir-.html.)

${ }^{2}$ bkz. 11 Ekim 2019 tarihli Resmî Gazete
} 
yalnızca görsel-işitsel kaynaklardan sunulmamaktadır. Bazı bilgiler yazılı olarak da sunulmaktadır. Sağır ve işitme engelli kesim söz konusu olduğunda bu kaynakların çevirisi de önem kazanmaktadır. Geniş toplumda oldukça yaygın bir yanılgı ise belli bir yaşın üstünde olan tüm Sağır ve işitme engelli bireylerin Türkçe yazılı kaynaklara tam erişimi olduğudur. Bu iki gerçeği ve nedenlerini irdeleyerek Türkiye'de Sağır bireylerin bilgiye erişimi hakkında daha sağlıklı bir görüş edinilebilir.

Her şeyden önce Sağır ve işitme engelli kitlenin büyüklüğüne bakmak ve buna göre bir iletişim/bilgi iletimi stratejisi geliştirmek önemlidir. Türkiye'de Sağır ve işitme engelli bireylerin sayısı hakkında bazı çelişkili veriler bulunabilmektedir. İlkbaşaran'a göre (2013) 2002 yılında yapılan resmî araştırma uyarınca Türkiye'de toplumun \%0.37'inde işitme kaybı vardır. Ancak, T.C. Aile, Çalışma ve Sosyal Hizmetler Bakanlığının 2019 yılına ait Engelli ve Yaşlı İstatistik Bülteninde bu oran \%1.1 olarak belirtilmiştir (T.C. Aile, Çalışma ve Sosyal Hizmetler Bakanlığı, 2019, 53). Kemaloğlu (2016, s. 63) Türkiye'de Türk İşaret Dilini ana iletişim dili olarak kullanan bireylerin sayısını 84.000-180.000 kişi (toplumun yaklaşık \%0.13 - \%0.27 arası) olarak belirtir. Dolayısıyla, tüm Sağırların Türk işaret dili ile sunulan bilgiye erişimi olduğunu ifade etmek de doğru olamayabilecektir.

Araştırmacılar (örneğin, bkz. Kemaloğlu \& Kemaloğlu, 2012) Türk Sağır topluluğundaki TiD yetkinliği konusunda bireyler bazında farklılıklar olabileceğine işaret ederler. Araştırmacılar bunun nedeninin de Türkiye'de benimsenen eğitim yaklaşımından kaynaklandığını öne sürerler. Yapılan bir başka araştırmada engelli bireylerin okuma yazma oranlarına da göndermede bulunulmuş ve Türkiye'de toplumun yaklaşık \%12.9'u okuma yazma bilmezken, bu oranın engelliler arasında üç katına çıktığı (\%36.3) ortaya konmuştur (bkz. Düşler Akademisi, 2018, s. 18; Tufan \& Arun, 2006). Günümüzde, sağır ve işitme engellilere yönelik benimsenen eğitim yaklaşımının düşük akademik başarıyı getirdiği hatta bazı Sağır ve işitme engelli mezunların okuma yazma becerisi edinmeden mezun oldukları çeşitli araştırmalarda vurgulanmaktadır (örneğin bkz. Illkbaşaran, 2013; Kubuş vd., 2016). Dolayısıyla, araştırmaların ve verilerin de ortaya koyduğu bilgiler ışığında Türkiye'de Sağır ve işitme engelli topluluğa bilgi iletilmesi için hem yazılı kanalların hem de işaret dili ile çevirinin kullanılması doğru olabilecektir.

Bu düşünceden hareketle, COVID-19 salgını döneminde Türkiye'de tüm kitlelerle paylaşılması öngörülen 14 Kuralın hem yazılı sürümünün hem de işaret dili ile çevirisinin sunulması doğru bir yaklaşımdır. Bu yaklaşımın doğruluğunu benimsemiş olan T.C. Aile, Çalışma ve Sosyal Hizmetler Bakanlığı, koronavirüse karşı "14 altın kural"ı işaret diline çevirtmiştir. Sağır ve işitme engelliler için işaret dilinde hazırlanan video "Koronavirüs Riskine Karşı Uymamız Gereken 14 Kural" başlığıyla sunulmuştur. Bakan Zehra Zümrüt Selçuk'un da sosyal medya hesaplarından paylaştığı videoyla, koronavirüsten korunmaya yönelik Sağıık Bakanlığınca belirlenen kuralların, işitme engelliler için de erişilebilir hâle getirildiği bildirilmiştir (Anadolu Ajansı, 2020). Aynı kuralların bir başka çevirisi ise, 'Koronavirüs Riskine Karşı 14 Kuralı Türk İşaret Diline Çeviri Yaptık' başlığı altında, Türkiye Sağırlar Konfederasyonu Başkanı Orkun Utsukarcı 
tarafından hazırlanmıştır (bkz. Sağırlar Konfederasyonu, 2020). Sözü edilen video i3 Medya platformunda yayımlanmıştır. Platform kendini şu sözlerle tanıtmaktadır:

Sağırlar olarak kendi dünyamızı geliştirmek ve daha eğlenceli bir hâle getirebilmek için başta komedi olmak üzere birçok konuda videolar çekmekteyiz. Bu sayede güncel, daha faydalı, daha etkili ve daha ulaşılabilir bir sayfa olduk. Desteklerinizle daha iyi yerlere gelmeyi hedefliyor ve hep beraber çok şey öğrenip başarılı olma yolunda emin adımlarla ilerliyoruz. (bkz. i3 Medya, 2020)

Açıklamadan da anlaşılacağı üzere platform özel olarak Türkiye'deki Sağır topluluk için tasarlanmıştır. Ayrıca, 14 Kuralın yazılı ve görsel destekli sürümüne ise T.C. Sağlık Bakanlığına ait yukarıda belirtilen sekmeden erişilebildiğinin de altını çizmek gerekir. Dolayısıyla, Sağır ve işitme engelli birey kendi gereksinim ve tercihleri doğrultusunda hareket ederek, ister resmî kurumların hazırladığı çeviriye, ister STK'ların hazırladığı sürüme, isterse de yazılı sürüme erişebilmektedir. Hatta üç ayrı platformdan kuralları inceleyebilmektedir.

Bu kuralların gerek yazılı sürümlerinin gerekse işaret diliyle çevirilerinin erişim açısından incelenmesi birkaç nedenle önemlidir. Birincisi, kamu sağlığının tehdit edildiği durumlarda doğru bilgi yayılımı önemlidir. Ikincisi, benzer bir durumla veya hâlihazırdaki koşulların devamında Sağır ve işitme engelli topluluklarla sağlıklı iletişim sağlanması ve bilgi akışı sağlanması açısından bir ilk olarak 14 Kuralın çevirisi önemli bir örnek oluşturmaktadır. Üçüncü olarak da işaret diline 2 ayrı çevirisi olan 14 Kuralın iletiminde kullanılan farklı yaklaşımlar ileride benzer çevirilere ışık tutabilecek niteliktedir.

\section{14 Kural ve Türk İşaret Dilinde Çevirisi}

14 Kuralın biçemini incelediğimizde, sade ve anlaşılır bir dille kaleme alındığı ve çoğu ortamda açıklayıcı görsellerle desteklenerek sunulduğu gözlemlenebilir. Görsel destekler de 14 kuralın içselleştirilmesi için önem teşkil etmektedir. Örneğin, aşağıdaki afiş Karabük Belediyesinin sitesinden alınmıştır (bkz. https://images.app.goo.gl/jGeBvYHvhxTsxcxq6). Çoğu ortamda asılı duran ve çevrimiçi olarak yayılan örneğe benzemektedir. 


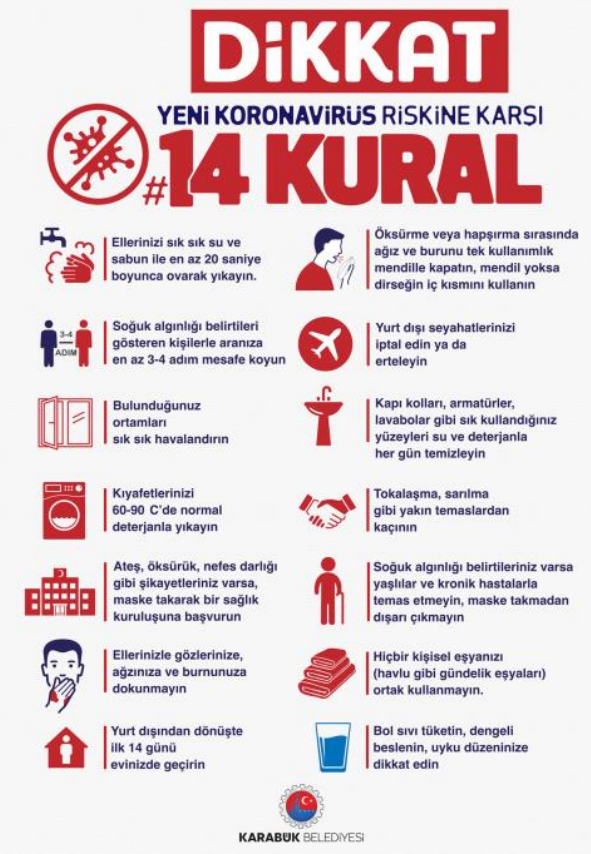

Görsel ögeler anlamayı ve algılamayı destekleyecektir. Sağır ve işitme engelli bireyler görsellere erişebilecekleri için, yukarıdaki örnekte sunulan afişlerin (veya örneğin videoların) görsel ögelerinin de incelenmesi önemli görülmektedir. Bu konuda üretilen ve yaygın olarak sunulan video, "Sizi ve Türkiye'yi Koronavirüs riskinden koruyacak 14 Kural" adı altında yayımlanmaktadır. YouTube kanalından görsel destek ve bir anlatıcının yazılı metinleri okuması ve sunması desteğiyle iletilmektedir (bkz. T.C. Sağlık Bakanlığı, Mar 14, 2020).

Görsel içerikler incelendiğinde birkaç konu göze çarpmaktadır. Genel olarak örneklerine bakıldığında 14 Kuralın her biri ayrı ayrı listelenerek sunulmaktadır. Akıcı bir metinden çok madde madde oluşturulmuş bir liste söz konusudur. Görsel desteğin (resimlerin, çizimlerin) sunulduğu ortamlarda genel olarak benzer görseller kullanılmaktadır. Bunları kısaca aşağıdaki şekilde listeleyebiliriz:

- El yıkama ve sabun kullanımı ile ilgili 1. Kuralda genelde el, musluk ve köpük görselleri gözlemlenmektedir.

- Sosyal mesafe ile ilgili 2. Kuralda genelde iki birey ve aralarındaki mesafeyi belirtecek bir 'ayırıcı unsur' (ok, metre ölçüsü vb.) resmedilmektedir.

- Ortam havalandırması ile ilgili 3. Kuralda genelde açık bir pencere ile görsel destek sağlanmaktadır.

- Kıyafetlerin yıkanması ile ilgili 4. Kuralda genelde bir çamaşır makinesi görseli sunulmaktadır.

- Sağlık kuruluşuna başvurulması gereken durumların anlatıldığı 5. Kuralda üzerinde hastane işaret olan bir kurum binası gözlemlenmektedir. 
- Ellerle yüze dokunulmaması ile ilgili 6. Kuralda elinde 'mikropla' ağzını kapayan bir birey resmedilmektedir.

- 14 gün karantina süresi ile ilgili 7. Kuralda bir ev çizimi içinde tek başına duran birey verilmektedir.

- Damlacık salınımı ile ilgili 8. Kuralda elindeki mendille ağzını kapayan bir birey sunulmaktadır.

- Yurtdışı seyahatlerle ilgili 9. Kuralda bir uçak resmi verilmektedir.

- Yüzeylerin temizlenmesi ile ilgili 10. Kuralda bir lavabo resmedilmektedir.

- Dokunarak temasa karşı uyarıda bulunan 11. Kuralda tokalaşan iki kişinin elleri çizilmiştir.

- Yaşlılar ve hastalarla temastan kaçınmakla ilgili 12. Kuralda elinde bastonu olan bir figür sunulmaktadır.

- Kişisel eşyaların ortak kullanımından kaçınılması ile ilgili 13. Kuralda katlanmış eşyalar görülmektedir.

- Su tüketimi, beslenme ve öz bakım ile ilgili 14. Kuralda ise bir bardak su resmedilmiştir.

Görsel destek bir yandan altı çizilen uyarıya vurgu yapmakta, diğer yandan da ek bilgi/açıklama sunmaktadır. Ayrıca, görsel destek oldukça kısa olan kurallarda en önemli unsurun ne olduğuna vurgu yapmaktadır. Bu da çeviriyi ve çevirmeni de destekleyecek ve yönlendirebilecek bir unsurdur.

14 Kuralın yukarıdaki bölümde sözü edilen iki çeviri sürümü bu bölümde birkaç farklı bakış açısından ele alınmaktadır.

Birinci bakış açısı "ürünün ne amaçla" yapıldığı ile ilgilidir ve bu da çeviride Skopos kuramı ve çeviriye ilişkin eylem kuramı ile açıklanabilir. Holz-Mänttäri, çeviriye ilişkin eylem kuramını kısaca şu şekilde açıklar: her eylemin bir amacı olduğu için bir eylem olan her bir çevirinin de amacı iletişim işlevini yerine getirmesidir. Burada öne çıkan etmen çevirinin erek kültürde belirlenen amacı yerine getirme kaygısıdır (TahirGürçağlar, 2011, s. 121). Çevirmen amacın belirlenmesinde erek kitlenin beklentilerini (gereksinimlerini) ön planda tutar ve kültürlerarası iletişimde belli bir amaç doğrultusunda erek metin üreten uzmandır. Skopos kuramına göre ise Vermeer de Holz-Mänttäri gibi, her eylemin bir amacı olduğunu belirtir. Vermeer'e göre her eylemin sonunda bir sonuç, yeni bir durum, olay oluşur. Çeviriye ilişkin eylemin sonucunda ise hedef metin meydana gelir. Vermeer buna translatum (çeviri metin) da demektedir (Reiss \& Vermeer, 2014). Çeviri işi başlamadan, çevirmenin çeviri sürecinde yerine getirmesi beklenen amacı genelde işveren tarafından belirlenir.

Sözü edilen iki çeviri sürümünün ne amaçla yapıldığı sorusunun cevabı aynıdır: iki sürüm de geniş toplumun erişebildiği 14 Kurala Sağır ve işitme engelli kitlenin de erişmesi için yapılmıştır. Dolayısıyla, eylemde 14 Kuralın (alıcı kitlenin gereksinimleri ve profilleri göz önüne alınarak) açık ve anlaşılır bir şekilde iletilmesi ilkesi benimsenmiş olması beklenir. 
İkinci olarak, söz konusu çevirinin "kimin tarafından talep edildiği" konusu vardır. Sözü edilen iki sürümün 'işvereni' farklıdır. Birinci sürüm T.C. AÇSHB tarafından resmî bir video olarak hazırlanmışken, ikinci sürüm bir STK tarafından temsil ettiği bir kitleye yönelik olarak görevini yerine getirmek amacıyla yapılmıştır. Her metnin söylemi ve dolayısıyla her çevirisi nötr değildir (bu bağlamda söylem çözümlemesi için bkz. Van Dijk, 2005). Kurumlar da belli metinlerin ve söylemlerin benimsenmesi ve yayılmasında merkezî bir rol oynarlar (bkz. Mills, 2004). Dolayısıyla, iki çeviri sürüm arasında bazı söylemsel farkların olması beklenir.

Üçüncü konu ise çevirmen tarafından belirlenen çeviri yaklaşımları ile ilgilidir. Çevirmen bu gibi bir bilgilendirme metni söz konusu olduğunda ya yazılı metinden sözlü çeviri yapabilecektir ya da benimsediği amaç ve işverenin talepleri doğrultusunda bu metinden yola çıkarak (kaynak metni ana metin olarak kabul ederek) bilgi içeriği ve amacı açısından farklılık göstermeyecek bir erek metin oluşturacaktır. Dolayısıyla, birinci yaklaşımda kaynak metne biçemsel sadakat gösterilecekken, ikinci yaklaşımda daha 'serbest' bir çeviri yaklaşımı benimsenebilecektir. Bu iki yaklaşımın arasındaki farkı anlatmak için yazılı metinden sözlü çeviri türünü açıklamak gerekecektir.

Yazılı metinden sözlü çeviride kaynak metin yazılı bir metinken, erek metin sözlü bir metin olarak iletilir. Kaynak metnin okunması ve erek dilde iletimi eşzamanlı yapıldığı için uzmanlar tarafından bir tür eşzamanlı çeviri olarak nitelendirilir (Ginori \& Scimone, 2001, s. 18). Ancak eşzamanlı bir çeviri türü olmasına rağmen iletinin düzeltilmesi ve revizyonu yapılabilir (Pöchhacker, 2004, s. 19). Padilla, (1995) gibi uzmanlar söz konusu çeviri ediminde çevirmenin metnin bir kısmını okurken bir diğer kısmını dillendirmesi gerektiği için bu alanda profesyonel becerilerin önemine dikkat çekerler. Gonzalez vd. (1991, s. 401) yazılı metinden sözlü çeviride kaynak metne sadakat ve akıcı ve doğal bir erek metin oluşturulmasının esas olduğuna vurgu yaparlar. Stansfield (2008) genelde daha resmî olan bir yazı dilinden sözlü bir ileti oluşturulmasını içeren yazılı metinden sözlü çevirinin eğitim gerektiren zorlu bir uğraş olduğuna dikkati çeker.

Üçüncü konu ile bağlantılı olarak, özünde yazılı bir metinden bir iletişim dili olan işaret diline iletimde çevirmenin yetkinliği de çeviri yaklaşımı açısından önemli bir rol oynar. Diğer sözlü çeviri türlerinden (örn. simultane ve ardıl çeviri) farklı olan yazılı metinden sözlü çeviride bütünlüklü metin çeviren kişinin elindedir (Agrifoglio, 2004, s. 44; Gile, 1997, s. 204). Dolayısıyla, çevirmenin hafızasına binen edim yükü farklıdır (Gile, 1997, s. 203) yani, kısa dönem hafızasını farklı şekilde kullanır. Ayrıca, çevirmenin çeviriyi sunum hızı takip etmesi gereken bir konuşmacı olmadığı için kendisi tarafından belirlenecektir (Gile, 1997, s. 203). Ancak, edimi betimlenen şekilde gerçekleştirebilmesi için söz konusu kişinin yazılı metinden sözlü çeviri konusunda deneyimi olması ve/ya eğitimi olması gerekir. Aksi takdirde yapılan çeviri bir anlatıya dönüşür. Makalede çalışılan konu (COVID-19'a ilişkin bilgilendirme) bağlamında yanlış bir yaklaşım olmayabilecektir- zira amaç bilgi paylaşımıdır. Ancak, oluşturulan metin, kaynak metni esas alarak ortaya konan bir yeniden yazım metni olmalıdır. Yeniden yazım bu bağlamda bir metinden yola çıkarak belli bir ideoloji, bir poetika ile oluşturulan ikinci bir erek metne işaret eder (Hermans, 2004, s. 127). Bu bir açıdan 
çeviridir bir diğer açıdan ise kaynak metnin bir yansıtımıdır. Yazılı bir metin ele alındığında bunun yeniden yazımı ya da yazılı metinden sözlü çevirisinin mi benimseneceği ise yine çevirinin amacına ve işverene bağlı olarak değişecektir.

Dolayısıyla, anlatılan konulardan özetle, aşağıdaki bölümde incelenen iki çeviri sürüme bakıldığında bunların ne amaçla yapıldığı, ne şekilde üretildiği ve ne şekilde sunulduğu göz önüne alınmalıdır. Bu bilgiler ışığında 14 Kuralın iki çeviri sürümü aşağıdaki bölümde incelenmektedir.

\section{14 Kuralın İşaret Diline Çevirilerinin İncelemesi}

İşaret dili çevirisi alanı Türkiye'de son on yılda ilgi görmeye başlamıştır. Günümüzde halen lisans düzeyinde işaret dili çevirmeni eğitimi mevcut değildir. Yüksek lisans düzeyinde eğitim ise Ankara Üniversitesi ve Hacettepe Üniversitesi tarafından sunulmaktadır. İşaret dili çevirisine odaklanan çalışmaların sayısı ise daha da azdır. Bu konudaki az sayıdaki eserden bir tanesi Oral (2017) tarafından kaleme alınmıştır. Söz konusu çalışma alana katkı sağlayan ve Türkiye'de işaret dili çevirisi konusuna odaklanan bir çalışmadır. Ancak, çalışmada yazarın da kabul ettiği gibi, karşılaştırmalı işaret dili çevirileri incelemeleri yapılmamakta ve özellikle de Sağır çevirmen ile CODA çevirmenin çevirileri incelenmemektedir. Söz konusu çalışmada ise bu iki çevirmen profiline uyan kişilerin çevirileri amaçları, kapsamları vb. açısından karşılaştırılmaktadır.

Çalışmada kullanılacak karşılaştırma yönteminde amaç diller arası farkı vurgulamak değildir. Ayrıca, Türk işaret dilinin özelliklerine odaklanılmamaktadır. Çalışmanın odak noktası 14 Kural ile ifade edilen bilgidir. Bu bilginin diller arası geçişteki aktarım şeklini daha açık bir şekilde ortaya koyabilmek için konvansiyonel işaret dili çeviri yazım tekniği kullanılmamış ve kaynak metne yapılan ekleme ve çıkarmaları saptamak amacıyla sadece 'anlam odaklı' birer döküm sunulmuştur. Çalışmanın inceleme bölümünde, (bölüm sonunda da açıklanacağı üzere) T.C. Aile, Çalışma ve Sosyal Politikalar Bakanlığı tarafından yapılan çeviri kaynak metne sadık ve anlam odaklı bir çeviri yaklaşımıyla yapılmıştır. Bu nedenle de bu çeviri ile ilgili yorumlar kısıtlı kalmakta, kaynağına sadık ve anlam odaklı bir çeviri yapıldığı dışında bir yorumda bulunulamamaktadır. Ancak, iki çeviriyi karşılaştırmak amacıyla , aşağıda kaynak metnin ve iki çeviri sürümün dökümleri sunulmaktadır:

\begin{tabular}{|l|l|l|}
\hline \multicolumn{1}{|c|}{ Kaynak metin $^{3}$} & \multicolumn{1}{|c|}{ Resmî Çevirisi $^{4}$} & \multicolumn{1}{|c|}{ STK çevirisi $^{5}$} \\
\hline $\begin{array}{l}\text { 1. Ellerinizi sık sık su ve sabun } \\
\text { ile en az 20 saniye boyunca } \\
\text { ovarak yıkayın. }\end{array}$ & $\begin{array}{l}\text { 1. Eller hep hep (vurgulama) } \\
\text { su sabun en az 20 saniyeye } \\
\text { göre yıkamak yapmak lazım. }\end{array}$ & $\begin{array}{l}\text { Merhaba bugün konu çok } \\
\text { önemli haber K+o+r+o+n+a } \\
\text { V+i+r+ü+s(parmak abecesi) K } \\
\text { virüs için problem Koronavirüs } \\
\text { hakkında. Şimdi Sağlık Bakanı }\end{array}$ \\
$\begin{array}{l}\text { 2. Soğuk algınlığı belirtileri } \\
\text { gösteren kişilerle aranıza en az } \\
\text { 3-4 adım mesafe koyun. }\end{array}$ & $\begin{array}{l}\text { 2. Soğuk, grip, öksürük göre } \\
\text { kişi o mesafe geri göre (kişi } \\
\text { konumlaması yaparak kişiyi }\end{array}$ & $\begin{array}{l}\text { Fahrettin Koca (parmak } \\
\text { abecesi ) beyefendi 14 madde }\end{array}$ \\
\hline
\end{tabular}

\footnotetext{
${ }^{3}$ Sağıık Bakanlığı resmî web sitesinden alındığı sırayla verilmiştir.

${ }^{4}$ Çevirinin işaret dilinden dökümü için Sayın Banu Türkuğur Şahin'e teşekkür ederiz.

${ }^{5}$ Çevirinin işaret dilinden dökümü için Sayın Berrak Fırat'a teşekkür ederiz.
} 
3. Öksürme veya hapşırma sırasında ağız ve burunu tek kullanımlık mendille kapatın. Mendil yoksa dirseğin iç kısmını kullanın.

4. Tokalaşma, sarılma gibi yakın temaslardan kaçının.

5. Ellerinizle gözlerinize, ağzınıza ve burnunuza dokunmayın.

6. Yurt dışı seyahatlerinizi iptal edin ya da erteleyin.

7. Yurt dışından dönüşte ilk 14 günü evinizde geçirin.

8. Bulunduğunuz ortamları sık sık havalandırın.

9. Kıyafetlerinizi 60-90 $C^{\prime}$ de normal deterjanla yıkayın.

10. Kapı kolları, armatürler, lavabolar gibi sık kullandığınız yüzeyleri su ve deterjanla her gün temizleyin

11. Soğuk algınlığı belirtileriniz varsa yaşlılar ve kronik hastalığı olanlarla temas etmeyin, maske takmadan dışarı çıkmayın.

12. Havlu gibi kişisel eşyalarınızı ortak kullanmayın.

13. Bol sıvı tüketin, dengeli beslenin, uyku düzeninize dikkat edin.

14. Düşmeyen ateş, öksürük ve nefes darlığınız varsa, maske takarak bir sağlık kuruluşuna başvurun. gösterir) 3-4 adım geri mesafe.

3. Yer göre ev iş ortam (çevre), hava, pencere aç aç (vurgulama), kapı aç aç (vurgulama) hava karşılıklı

4. Kıyafet $60-90$ derece göre normal ben su deterjan göre çamaşır makine yapmak.

5. Ateş, öksürük, nefes yetmemek göre var tama(sa) maske için var o hemen sağlık hastane doktor başvur git yap.

6. El, göz, ağız, burun ovma yapmak değil.

7. Memleket dış ben uçak gelmek, (vurgulama) var+ama(sa) ilk 14 gün göre ev kal yap.

8. Öksürme, hapşırık çeşit göre mendil hapşırmak yap dikkat lazım. Mendil yok+ama (sa), (dirsek iç kısmını gösterdikten sonra) dikkat hapşırık yap dikkat lazım.

9. Memleket dışı var iptal ya da ertelemek yap.

10. Kapı, kol, musluk, el yıkama çeşit su deterjan koymak, temizlemek silmek yap.

11. Tokalaşmak, sarılmak çeşit uzak (elleri birbirinden uzaklaştırma), uzak hayır yapmak lazım.

12. Nezle, öksürük kendi göre var(sa) yaşlı, hasta, ağır talimat vermek. Sağır toplum uyanmak bilgi vermek herkes dikkat çekmek önemli.

14 şart ne?

1. Birinci Önemli olmak el bol bol yıkamak (görsel vurgu ve şekil işaretle verilmekte) su bol bol 20 saniye istemek 30 saniye yıkamak son bitti temiz olmak lazım.

2. İkinci madde önemli olmak sağır ya da duyan birisi hasta yüzü tuhaf karşılamak yakınlaşmak yok 3-4 adım geri yürümek ayak geri basmak geride idare etmek kendi dikkat çekmek kendi korumak lazım.

3. Bir kişi hasta içi ne var hapşırmak idare kendi çekilmek o kişi hapşırmak ya da öksürmek olmak mendil burun ağız kapamak korumak lazım veya mendil yok acele kol/dirsek ağız kapamak kendi korumak lazım kendi o çekilmek dikkat çekmek lazım.

4. Karşılaşmak o hasta var mı yok virüs bilmemek önemli olmak el tokalaşmak olmamak sarılmak olmamak uzak mesafe selamlaşmak (merhaba merhaba) mesafe kendi dikkat etmek ben korumak lazım.

5. Burun ağız göz kulak oynamak el kullanmak yapmamak kendi dikkat almak bir virüs var el hava gelmek el yüz oynamak göz girmek çabuk hasta çıkmak ağız için girmek hasta çıkmak el yüz (kulak ağız göz) yapma el oynamak yapma el pis olmak yüz yapma hep el 


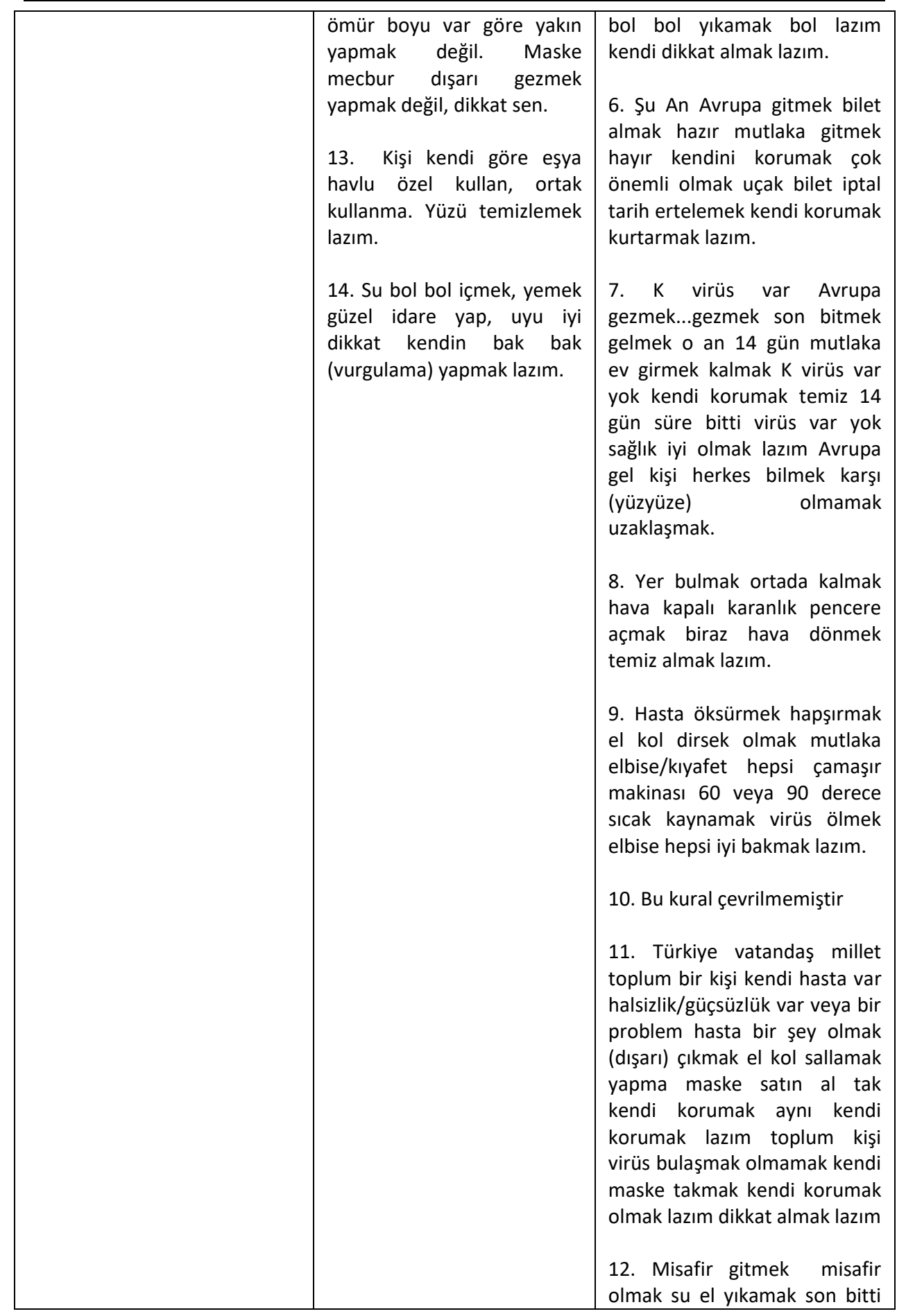




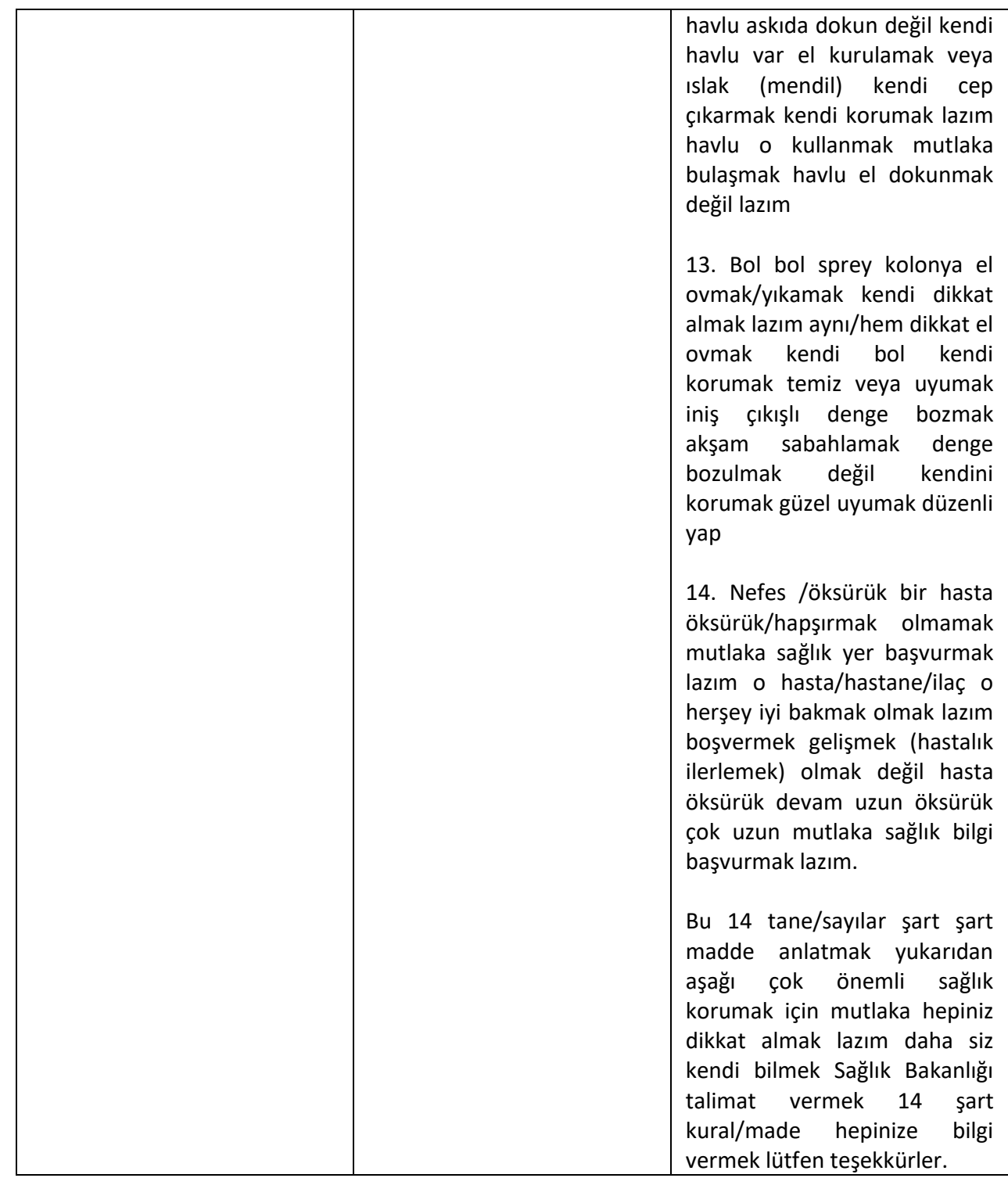

Birincisi ne resmî bilgilendirmede ne de STK'nın çevirisinde görsel destek verilirken, kuralların resmî çevirisinde kuralların (çevrildiği sırayla) yazıı dökümü verilmiş ve videoda bir anlatıcı kuralları sesli olarak okumuştur.

íkincisi her sürümde kuralların sırası değiştirilmiştir.

Üçüncüsü STK'nın ürettiği çeviride kaynak metnin bir 'sunumu' yapılmakta ve 14 Kuralın ne olduğu anlatılmaktadır (Merhaba bugün konu çok önemli haber $k+0+r+o+n+a \quad v+i+r+u ̈+s$ (parmak abecesi) $K$ virüs için problem. Şimdi Sağlık Bakanı Fahrettin Koca (parmak abecesi) beyefendi bir şart 14 madde talimat vermek Sağır 
Toplum uyanmak bilgi vermek herkes dikkat çekmek önemli 14 şart ne?). Sonunda ise çevirmen "anlatıcı rolü" üstlenerek alıcılara kişisel bir uyarıda bulunmaktadır (Bu 14 tane/sayılar şart şart madde anlatmak yukarıdan aşağı çok önemli sağlık korumak için mutlaka hepiniz dikkat almak lazım daha siz kendi bilmek Sağlık Bakanlığı talimat vermek 14 şart kural/madde hepinize bilgi vermek lütfen teşekkürler.) Bu farklılığın çevirilerden birinin kuralların resmî çevirisi, diğerinin ise bir STK'nın bilgilendirme amaçlı çevirisi olmasından kaynaklandığı düşünülmektedir. Bu yaklaşım da yukarıdaki bölümde Skopos kuramı çerçevesinde çevirisinin üretim amacı ile ilgilidir: Resmi çeviri kaynak metni aynıyla aktarmaya odaklanırken STK tarafından yapılan çeviride ek bir bilgilendirme amacı da güdülmüştür.

Dördüncü olarak iki çeviri ve kaynak metin arasında bazı farklılıklara rastlanmaktadır. Bu farklılıkları belli başlıklar altında gruplayarak incelemek olasıdır. Bu bağlamda işaret dilinin kendi yapısından kaynaklanan (örneğin, vurgu yapılması için sözcüğün/işaretin tekrarlanması vb. gibi) farklılıkların dilsel farklılık olarak tanımlanacağı için çalışma kapsamında 'farklılık', veya kayma olarak belirtilmediğine dikkat çekmek gerekir. Çeviri farklılıkları aşağıdaki gibi gruplanabilir.

Bazı yerlerde çeviri sürüm(ler)de kaynak metne bilgi eklendiği gözlemlenebilir. Bilgi eklenmesi ile ifade edilen farklılaşma kaynak metinde açıkça belirtilmeyen bir bilginin çeviride açıkça aktarılmasıdır. Aşağıda bu konuya beş örnek verilmiştir.

Yazılı sürümde "Ellerinizi sık sık su ve sabun ile en az 20 saniye boyunca ovarak yıkayın" olarak belirtilen birinci kuralı, STK tarafından yapılan çeviride "Önemli olmak el bol bol yıkamak aralarını ovalayarak ovuşturarak su bol bol 20 saniye istemek 30 saniye yıkamak son bitti temiz olmak " olarak iletilmiş ve yıkama süresi konusunda ek bilgi verilirken 'parmak aralarını ovalamak, ovuşturmak' gibi bir betimleme eklenmiştir.

Yazılı sürümde "Soğuk algınlığı belirtileri gösteren kişilerle aranıza en az 3-4 adım mesafe koyun," olarak belirtilen ikinci kural, STK tarafından yapılan çeviride "ikinci madde önemli olmak sağır ya da duyan birisi hasta yüzü tuhaf karşılamak yakınlaşmak yok 3-4 adım geri yürümek ayak geri basmak geride idare etmek kendi dikkat çekmek kendi korumak lazım" olarak iletilmiş ve bireyin Sağır ya da duyan birisi olması bilgisi eklenmiştir.

Yazılı sürümde "Öksürme veya hapşırma sırasında ağız ve burunu tek kullanımlık mendille kapatın. Mendil yoksa dirseğin iç kısmını kullanın" olarak belirtilen üçüncü kural STK tarafından yapılan çeviride "Bir kişi hasta içi ne var hapşırmak idare kendi çekilmek o kişi hapşırmak ya da öksürmek olmak mendil burun ağız kapamak korumak lazım veya mendil yok acele kol/dirsek ağız kapamak kendi korumak lazım kendi o çekilmek dikkat çekmek lazım" olarak iletilmiştir. Hapşıran kişiden uzak durulması gerektiği bilgisi, bireyin kendisini ve karşısındakini koruması gerektiği vurgusu eklenmiştir.

Yazılı sürümde "Tokalaşma, sarılma gibi yakın temaslardan kaçının" olarak belirtilen dördüncü kural STK tarafından "Karşılaşmak o hasta var mı yok virüs bilmemek önemli olmak el tokalaşmak olmamak sarılmak olmamak uzak mesafe selamlaşmak (merhaba merhaba) mesafe kendi dikkat etmek ben korumak lazım." 
olarak aktarılmış, bu çeviride yakın temastan kaçınılırken "uzak mesafe selamlaşmak" ifadesiyle nasıl sosyal ilişki kurulabileceği de açıklanmıştır.

Yazılı sürümde "Bol sıvı tüketin, dengeli beslenin, uyku düzeninize dikkat edin" olarak belirtilen on üçüncü kural STK tarafından "Bol bol sprey kolonya el ovmak/yıkamak kendi dikkat almak lazım aynı/hem dikkat el ovmak kendi bol kendi korumak temiz veya uyumak iniş çıkışlı denge bozmak akşam sabahlamak denge bozulmak değil kendini korumak güzel uyumak düzenli yap" şeklinde iletilmiştir. Bu çeviride kaynak metinde olmayan "bol bol sprey kolonya" ifadesiyle dezenfektan kullanılması bilgisi ve "kendini korumak" ifadesi yinelenerek eklenmiştir.

Bazı yerlerde çeviri sürüm(ler)de kaynak metinden bilgi çıkarıldığı gözlemlenebilir. Bilgi eksiltilmesi ile ifade edilen farklılaşma kaynak metinde olan bir bilginin çeviride yansıtılmamasıdır. Aşağıda bu konuya altı örnek verilmiştir.

Yazılı sürümde "Soğuk algınlığı belirtileri gösteren kişilerle aranıza en az 3-4 adım mesafe koyun," olarak belirtilen ikinci kural, STK tarafından yapılan çeviride "İkinci madde önemli olmak sağır ya da duyan birisi hasta yüzü tuhaf karşılamak yakınlaşmak yok 3-4 adım geri yürümek ayak geri basmak geride idare etmek kendi dikkat çekmek kendi korumak lazım," olarak iletilmiş. Kaynak metindeki 'soğuk algınlığı belirtileri' ifadesi 'hasta görünmek' gibi genel bir anlatıyla sunulmuştur.

Yazılı sürümde “Kapı kolları, armatürler, lavabolar gibi sık kullandığınız yüzeyleri su ve deterjanla her gün temizleyin" olarak belirtilen onuncu kural STK'nın çevirisinde bulunmamaktadır.

Yazılı sürümde "Soğuk algınlığı belirtileriniz varsa yaşlılar ve kronik hastalığı olanlarla temas etmeyin, maske takmadan dışarı çıkmayın" olarak belirtilen on birinci kural STK'nın çevirisinde "Türkiye vatandaş millet toplum bir kişi kendi hasta var halsizlik/güçsüzlük var veya bir problem hasta bir şey olmak (dışarı) çıkmak el kol sallamak yapma maske satın al tak kendi korumak aynı kendi korumak lazım toplum kişi virüs bulaşmak olmamak kendi maske takmak kendi korumak olmak lazım dikkat almak lazım" olarak iletilmiş ve 'yaşlı ve kronik hasta' gibi risk gruplarına yapılan gönderme aktarılmamış, bir genelleme yaparak 'toplum' ifadesi kullanılmıştır.

Yazılı sürümde "Havlu gibi kişisel eşyalarınızı ortak kullanmayın” olarak belirtilen on ikinci kural STK çevirisinde "Misafir gitmek misafir olmak su el yıkamak son bitti havlu askıda dokun değil kendi havlu var el kurulamak veya ıslak (mendil) kendi cep çıkarmak kendi korumak lazım havlu o kullanmak mutlaka bulaşmak havlu el dokunmak değil lazım" olarak çevrilmiş ve havlunun kişisel eşyaya bir örnek olarak verildiği iletilmemiştir.

Yazılı sürümde "Bol sıvı tüketin, dengeli beslenin, uyku düzeninize dikkat edin" olarak belirtilen on üçüncü kural STK tarafından "Bol bol sprey kolonya el ovmak/yıkamak kendi dikkat almak lazım aynı/hem dikkat el ovmak kendi bol kendi korumak temiz veya uyumak iniş çıkışı denge bozmak akşam sabahlamak denge bozulmak değil kendini korumak güzel uyumak düzenli yap" olarak aktarılmıştır. Bu kuralda sıvı tüketimine yapılan vurgu çıkarılmıştır. 
Yazılı sürümde, "Düşmeyen ateş, öksürük ve nefes darlığınız varsa, maske takarak bir sağlık kuruluşuna başvurun," olarak iletilen on dördüncü kural, STK'nın çevirisinde "Nefes /öksürük bir hasta öksürük/hapşırmak olmamak mutlaka sağlık yer başvurmak lazım o hasta/hastane/ilaç o herşey iyi bakmak olmak lazım boşvermek gelişmek (hastalık ilerlemek) olmak değil hasta öksürük devam uzun öksürük çok uzun mutlaka sağlık bilgi başvurmak lazım”olarak iletilmiş ve bu gibi bir durumda maske takarak sağlık kuruluşuna gidilmesi gerektiği vurgusu çıkarılmıştır.

Bazı yerlerde çeviri sürüm(ler)de kaynak metne açıklama eklendiği gözlemlenebilir. Açıklama eklenmesi ile ifade edilen farklılaşma kaynak metinde kısaca ve/ya örtük olarak belirtilen bir genel bilginin açıklanarak/örneklenerek çeviride iletilmesidir. Aşağıda bu konuya dört örnek verilmiştir.

Yazılı sürümde "Tokalaşma, sarılma gibi yakın temaslardan kaçının" olarak belirtilen dördüncü kural STK tarafından "Karşılaşmak o hasta var mı yok virüs bilmemek önemli olmak el tokalaşmak olmamak sarılmak olmamak uzak mesafe selamlaşmak (merhaba merhaba) mesafe kendi dikkat etmek ben korumak lazım." olarak aktarılmış, bu aktarımda bu önlemin nedeni (bireyin kendisinin ve karşısındakinin hasta olup olmadığını bilememesi) eklenmiştir.

Yazılı sürümde "Ellerinizle gözlerinize, ağzınıza ve burnunuza dokunmayın," olarak belirtilen beşinci kural STK tarafından "Burun ağız göz kulak oynamak el kullanmak yapmamak kendi dikkat almak bir virüs var el hava gelmek el yüz oynamak göz girmek çabuk hasta çıkmak ağız için girmek hasta çıkmak el yüz (kulak ağız göz) yapma el oynamak yapma el pis olmak yüz yapma hep el bol bol yıkamak bol lazım kendi dikkat almak lazım" olarak iletilmiştir. Bu aktarımda bu önlemin nedeni (virüsün nasıl bulaşabileceği) hakkında bir açıklama eklenmiştir. Sonunda ise 'el yıkamak' (1. Kural) konusunda bir tekrar yapılmıştır.

Yazılı sürümde "Kıyafetlerinizi 60-90 C'de normal deterjanla yıkayın" olarak belirtilen dokuzuncu kural STK'nın çevirisinde "Hasta öksürmek hapşırmak el kol dirsek olmak mutlaka elbise/kıyafet hepsi çamaşır makinası 60 veya 90 derece sıcak kaynamak virüs ölmek elbise hepsi iyi bakmak lazım" olarak iletilmiştir. Bu aktarımda bu önlemin nedeni (yüksek ısılarda yıkmada virüsün ölmesi) hakkında bir açıklama eklenmiştir.

Yazılı sürümde "Havlu gibi kişisel eşyalarınızı ortak kullanmayın" olarak belirtilen on ikinci kural STK çevirisinde "Misafir gitmek misafir olmak su el yıkamak son bitti havlu askıda dokun değil kendi havlu var el kurulamak veya ıslak (mendil) kendi cep çıkarmak kendi korumak lazım havlu o kullanmak mutlaka bulaşmak havlu el dokunmak değil lazım" olarak çevrilmiştir. Çevirmen başkasının havlusunu kullanmama temasından hareketle alıcılara kâğıt havlu veya kendi havlularını kullanma önerisinde bulunmuştur. Buna ek olarak bu önlemin nedenini (başkasının havlusunu kullanırsanız virüs size bulaşır) açıklamıştır.

Bazı yerlerde çeviri sürüm(ler)de kaynak metnin yorumlandığı gözlemlenebilir. Yorumlama ile ifade edilen farklılaşma kaynak metindeki bir anlam biriminin 
amaçlanan anlamın dışına çıkılarak aktarılmasıdır. Aşağıda bu konuya üç örnek verilmiştir.

Yazılı sürümde "Yurt dışı seyahatlerinizi iptal edin ya da erteleyin" olarak belirtilen altıncı kural STK'nın çevirisinde “Şu An Avrupa gitmek bilet almak hazır mutlaka gitmek hayır kendini korumak çok önemli olmak uçak bilet iptal tarih ertelemek kendi korumak kurtarmak lazım" olarak iletilmiş ve kaynaktaki 'seyahat etmeyin' uyarısının nedeni açıklanarak "kendini korumak" ve kendini kurtarmak olarak ifade edilmiş ve önemi vurgulanmıştır.

Yazılı sürümde "Kıyafetlerinizi 60-90 C'de normal deterjanla yıkayın" olarak belirtilen dokuzuncu kural STK'nın çevirisinde "Hasta öksürmek hapşırmak el kol dirsek olmak mutlaka elbise/kıyafet hepsi çamaşır makinası 60 veya 90 derece sıcak kaynamak virüs ölmek elbise hepsi iyi bakmak lazım." olarak iletilmiş ve yukarıdaki örnektekine benzer bir şekilde belli bir ısıda kıyafet yıkayarak virüsün öleceği bilgisi açıklama yapılarak verilmiştir.

Yazılı sürümde "Bol sıvı tüketin, dengeli beslenin, uyku düzeninize dikkat edin" olarak belirtilen on üçüncü kural STK tarafından "Bol bol sprey kolonya el ovmak/yıkamak kendi dikkat almak lazım aynı/hem dikkat el ovmak kendi bol kendi korumak temiz veya uyumak iniş çıkışlı denge bozmak akşam sabahlamak denge bozulmak değil kendini korumak güzel uyumak düzenli yap" olarak aktarılmıştır. Bu çeviride de kaynak metinde olmayan dezenfektan kullanımı ve temizlik gibi eklemeler yapılarak çevirmen açıklama katmıştır.

Yukarıda ayrıntıları ile verilen karşılaştırma ışığında, resmî çeviride benimsenen çeviri yaklaşımının ve stratejilerinin STK tarafından yapılan çeviridekilerle ancak kısmen örtüştüğü ortadadır. Çevirmenler metni farklı yaklaşımlarla aktarmayı uygun görerek, farklı alt amaçlara hizmet edecek sürümler ortaya koymuşlardır.

\section{Sonuç}

COVID 19- 14 Kural çevirisi sağlık çevirmenliği kapsamında ele alınabilir. Hsieh (2016) bu alanda çevirinin belli bir amaca yönelik iletişim faaliyeti olduğunun altını çizer ve Roat ve Crezee'nin (2015, ss. 236-253) de vurguladığı gibi sağlık alanında sözlü çevirmenliğin çok dikkatle icra edilmesi gerekir. Makalede incelenen bağlamda bu amaç doğru bilgi aktarımı, bilgilendirme olarak belirlenmiştir.

Alan yazınında sağlık alanında çalışacak çevirmenlerin niteliklerini sıralayan çizelgeler olduğu gibi bazı durumlarda sağlık çevirmenlerinin profesyonel çevirmen olmadığı da gözlemlendiği kaydedilmiştir (örneğin bkz. Ho, 2008). Angelelli (2007) ve Pöchhacker ve Shlesinger (2007) gibi uzmanlar bu konuda ayrıntılı eserler vererek alanın zorluklarına, alanda çalışacak kişilerin niteliklerine, etik kurallara ve benzerine ışık tutmuşlardır.

Bu alanda yayımlanan birçok çalışmaya bakıldığında ortak bazı noktalar göze çarpmakta ve bir çeviri etiği benimsenmektedir. Bu etik kurallara bakıldığında ise hepsinde çevirinin kaynaktaki içeriği yansıtmasının önemine vurgu yapıldığı 
görülmektedir (örneğini bkz. IMIA 2006). Ancak, bu bağlamda incelenen kaynak metin her ne kadar sağlık konusunda olsa da ve çevirisi de toplum sağlığını ilgilendirdiği için bir toplum çevirmenliği edimi gibi düşünülebilse de, bir sağlık kuruluş içinde veya bir sağlık çalışanı ve sağlık hizmeti alıcısı arasında çeviri edimi söz konusu olmadığından, çalışmanın konusuyla yakından bağlantılı görülmemektedir. Ancak, bu bağlamda uygulanan çeviri yaklaşımları sağlık çevirmenliği kapsamında da düşünülebileceği için bu konuya değinilmiştir.

Çalışmanın giriş bölümünde belirtildiği gibi, pandemi döneminde toplumun her kesimine doğru ve eksiksiz bilgi aktarımı yapılması hayati önem taşır. Bu düşünceden hareketle, çalışmanın ilk bölümünde anlatıldığı üzere, toplumun geri kalanından farklı olarak geleneksel bilgiye erişim yöntemlerine erişimi olmayan Sağır ve işitme engelli topluluklar için alternatif çeviriler üretilmesi ve çeviri sürümler sunulması çok önemli bir gereksinime cevap verecektir.

Çalışmanın analiz bölümünde incelenen 14 Kural ve çevirisine bakıldığında resmi çevirinin kaynak metni aynıyla yansıtan profesyonel bir sürüm olduğu sonucuna varılabilir. STK tarafından ortaya konan sürüm ise Sağır ve işitme engelli topluluğu bilgilendirme, ek bilgi sunma ve açıklama amacı güden bir çeviri olarak düşünülebilir. Sonuç olarak, bu iki sürümün varlığı birbirini desteklemektedir. Yanlış bilgi iletilmediği sürece de içinde yaşadığımız dönem gibi dönemlerde birçok kanaldan aynı bilginin iletilmesi bilgiye erişimi kolaylaştırdığı gibi tekrarlardan dolayı bilginin içselleştirilmesi ve dikkate alınmasını da desteklemektedir.

Çalışmada söz edilen iki sürüme ek olarak 14 Kural başka kişiler ve/ya kurumlar tarafından da çevrilmiş ve internet ortamında çeviriler paylaşılmıştır ${ }^{6}$

İki çeviri sürüm birbirinden farklılaşsa ve kaynak metinden belli yerlerde farklılaşsa bile bu sürümleri 'eleştirel bir gözle' değil, hedeflenen amaca ulaşılıp ulaşılmadığı açısından incelemek gerekecektir.

Hedeflenen amaç kısaca Sağır ve işitme engelli bireylerin 14 Kural ile ilgili olarak doğru bir şekilde bilgilendirilmesidir. Buna ek olarak bu bilgilerin kendilerine birkaç farklı platformdan (bilginin doğruluğunu ve önemini vurgulayacak şekilde) iletilmesi sözü edilen bilginin dikkate alınması ve içselleştirilmesi açısından önem arz etmektedir.

T.C. Aile, Çalışma ve Sosyal Hizmetler Bakanlığı tarafından oluşturulan sürümde 14 Kural Bakanlık kadrosuna sınav ile alınmış ve yetkinliğini yıllardır kanıtlamış ve benzer görevleri başarıyla icra etmiş bir çevirmen tarafından, kaynağına sadık bir şekilde aktarılmıştır. Bu aktarımda yazılı olan kurallar ortamlar arası bir aktarımla (eng.

6 (örneğin bkz. https://www.sozcu.com.tr/hayatim/yasam-haberleri/isaret-dili-ile-corona-viruse-karsialinacak-14-kuralanlatildi/?utm_source=dahafazla_haber\&utm_medium=free\&utm_campaign=dahafazlahaber; https://www.haberler.com/isaret-dili-ile-korona-viruse-karsi-alinacak-14-13051965-haberi/). 
İntermedial- yazılı metinden görsel-işitsel ürün üretilmesi) sunulurken kaynak yazılı metin çalışmada sözü edilen görsel destekle (çizimlerle) desteklenerek verilmiştir.

STK'nın ürettiği çeviride ise amaç aynı olmakla birlikte farklı bir yaklaşım benimsenmiştir. Bir çevirmenden çok bir anlatıcı rolü üstlenen çevirmen bu rolünü aktarımın ilk başında ve sonunda eklediği açıklamalarla anlatmıştır (örn bkz. Merhaba bugün çok önemli bir konu hakkında bilgi vermek istiyorum. Koronavirüs hakkında. Şimdi sağlık bakanı Fahrettin Koca beyefendi 14 kural hakkında bilgi verdi. Sağır toplumun bilgilenmesine dikkat çekmek için önemli 14 kural ne? [...] Bu 14 kuralı sizlere anlattım lütfen sağlık bakanlığını 14 kuralına uyalım ve kendimize dikkat edelim lütfen.). Bu çevirmen çevirdiği 14 Kural için serbest çevirisine bir giriş ve sonuç mahiyetinde yanmetin (eng. Paratexts) oluşturmuştur. Batchelor'un (2018) de eserinde irdelediği üzere bir çeviriye eklenen yanmetinler sayesinde çevirmen çevirisini ve çeviri yaklaşımını açıklayabileceği gibi, çevirinin amacını da iletebilmekte ve buna ek olarak kaynak metinle ilgili ek bilgi paylaşabilmektedir. STK tarafından üretilen sürümde de bu yaklaşımın varlığı görülmektedir. Yanmetinin varlığı ise çevirinin iletim şeklini farklılaştırmıştır.

Bakanlığın ortaya koyduğu sürümde anlam odaklı bir çeviri görülürken, inceleme bölümünde irdelendiği üzere STK'nın sürümünde alıcı kitleye hitap edecek eklemeler ve açıklamalar gözlemlenmektedir. Bunlara örnek olarak alıcının kültürüne göndermeler (örn. Sağır ve duyan kişi), açıklamalar (örn. misafirlikte havlu kullanımı; virüsün yayılımı hakkında bilgi) ve tekrarlar (örn. dikkat edilmesi gerektiği, korunması gerektiği) ve bilgiye dayalı yanlış olmayan öneriler (örn. parmakların arasını ovalayarak yıkmak) verilebilir. Ortak bir iletişim dili kullanılmadığından geniş toplumla iletişimi kısıtlanan bir kitle söz konusu olduğunda, resmî kaynakların sunduğu bilgilerin toplumu temsil eden biri tarafından samimi bir biçemle ve gerekli açıklamalar yapılarak yinelenmesi, ancak bilginin perçinlenmesine ve içselleştirilmesine yarayacaktır.

Çalışma boyunca vurgulandığı üzere, doğru bilgi paylaşımının ve bilgiye erişimin çok merkezî önem taşıdığı pandemi süresince bir yandan devlet kurumlarının diğer yandan da STK'ların sağır ve işitme engelli toplulukları bilgilendirme görevini üstlenmeleri önemlidir. Bu görevi yerine getiren devlet makamları profesyonel bir CODA çevirmen ile çalışarak akıcı, iletişimsel ve kaynağına sadık kalarak doğru ve eksiksiz bilgi aktarımında bulunulan bir sürüm hazırlatmışlardır. STK'ların da bu konuda desteği olmuş ve kaynak metindeki bilgilere Sağır topluluğa hitap edecek, resmi söylemden ve kaynak metinden yer yer uzaklaşan ancak erek odaklı bir yaklaşımla iletilen bir çeviri ortaya konmuştur.

Bu gibi çevirilerin akademik ortamlarda incelenmesi aktarımda kullanılabilecek yaklaşımlara, farklı sürümlerin ortaya konmasındaki artılara işaret edebilir. Ayrıca, hâlen COVID-19 sürecinin devam ettiğinin, Sağır ve işitme engelli topluluğun bir defa değil her gün bilgiye erişmesinin önemli olduğunun altının çizilmesi gerekir. Hâlihazırda var olan çeviriler üzerinde sağlık çevirmenliği bakış açısından, sosyokültürel bağlam açısından, çevirmen nitelikleri ve seçimleri açısından yapılacak araştırmalar, Sağır ve işitme engelli topluluk arasında bilgilendirme ile ilgili anket çalışmaları ile görüşlerinin 
alınması günümüz pandemi koşullarında acilen üzerine düşülmesi gereken bir çalışma alanıdır.

Makalede örneklemeye çalıştığımız türden incelemeler bu alanda çalışmak isteyecek çevirmenlere yol gösterebileceği gibi, kurumlara ve kuruluşlara doğru çeviri ve bilgilendirmenin ve çoklu kanaldan bilgilendirmenin önemini vurgular niteliktedir. Devlet kurumlarının işaret dilinde resmî çeviri sürümlerini oluşturmaları, STK'ların temsil ettikleri kitleler için daha az resmî bir dille açıklama, anlatı tarzında bilgi videoları sunmaları ve bu metinler oluşturulurken doğru bilginin iletilmesi Sağır ve işitme engelli kitle için önemli olduğu kadar toplumun her kesimi için önem taşır. Bilgisizlik, eksik veya yanlış bilgi aktarımı yalnızca toplumun belli bir kesimini değil, pandemi olduğu bir durumda genel toplum sağ|ığını etkileyen bir durum hâline gelecektir.

Çalışmada incelenen türden çevirilerin daha sıklıkla yapılması, mümkün olan her platformdan yayımlanması ve toplumda her bireyin bilgiye tam erişimi olması artık yalnızca 'politik açıdan doğru olan bir uygulama' olmaktan çıkmıştır; aksi bir durum toplum sağlığını olumsuz etkileyecektir.

\section{Kaynakça}

Avrupa Engellilik Stratejisi. (2010). Türkiye Görme Engelliler Derneği. Erişim: 1 Kasım 2020. https://www.turged.org.tr/icerik.php?id=212

Agrifoglio, M. 2004. Sight translation and interpreting: A comparative analysis of constraints and failures. Interpreting. 6(1), 43-67.

Anadolu Ajansı. (2020). Koronavirüse karşı 14 altın kural işaret diline çevrildi. https://www.aa.com.tr/tr/vg/video-galeri/koronaviruse-karsi-14-altin-kural-isaret-dilinecevrildi/6

Angelelli C. V. (2007). Assessing medical interpreters. Translator, 13(1), 63-82.

Batchelor, K. (2018). Translation and Paratexts. Translation Theories Explored Series. Londra \& New York: Routledge.

Directive 2010/13/EU of the European Parliament and of the Council of 10 March 2010 on the coordination of certain provisions laid down by law, regulation or administrative action in the Member States concerning the provision of audiovisual media services (Audiovisual Media Services Directive), 2010. OJ L95:1-24. Son erişim: Kasım 2020. http://eur-lex.europa.eu/legal-content/EN/TXT/?uri=OJ \%3AC\%3A2013\%3A260\%3AFUL.

Düşler Akademisi. (2018). Sosyal etki raporu. https://sosyaletkianalizi.com/wpcontent/uploads/2018/01/DAsosyal-etki-raporu.pdf

Gile, D. (1997). Conference interpreting as a cognitive management problem, Joseph H. Danks, Gregory M. Shreve, Stephen B. Fountain, Michael K. McBeath, (Ed.) Cognitive Processes in Translation and Interpreting (ss. 196-214), Londra: Sage.

Ginori, L. Ve Scimone, E. (2001). Introduction to Interpreting. Bexley: Lantern Press.

Gonzalez, R. D., Vasquez, V. F. ve Mikkelson, H. (1991). Fundamentals of court interpretation: Theory, policy and practice. Durham: Carolina Academic Press.

Gürçağlar-Tahir, Ş. (2011). Çevirinin $A B C^{\prime}$ si. İstanbul: Say Yayınları. 
Hermans, T. (2004). Translation in Systems: Descriptive and System-oriented Approaches Explained. Shanghai: Shanghai Foreign Language Education Press.

Ho, A. (2008). Using family members as interpreters in the clinical setting. J Clin Ethics, 19(3):223-233.

Hsieh E. (2016). Bilingual health communication: working with interpreters in cross-cultural care. New York ve Londra: Taylor \& Francis Group.

i3 Medya. (2020). i3MEDYA Hakkımızda. http://www.kurumsal.i3medya.com/hakkimizda/

Ilkbaşaran, D. (2013). Communicative practices in Turkish Sign Language. Arık, E. (Ed.), Current directions in Turkish Sign Language Research (ss. 19-53). Newcastle upon Tyne: Cambridge Scholars Publishing.

IMEA (International Medical Interpreters Association). (2006). Code of ethics for medical interpreters. https://www.imiaweb.org/uploads/pages/376.pdf.

Kemaloğlu, Y.K. \& Yaprak Kemaloğlu, P. (2012). The history of sign language and Deaf education in Turkey. Kulak Burun Bogaz ihtisas Dergisi, 22(2), 65-76.

Kemaloğlu, Y. (2016). Türkiye'de Sağırların Görünürlüğü ve Toplumsal ve Eğitimsel Sorunları Üzerine Demografik Bir İnceleme. Arık, E. (Ed.), Ellerle Konuşmak: Türk işaret Dili Araştırmaları (ss. 51-79). İstanbul: Koç Üniversitesi Yayınları.

Kubuş, O., Illkbaşaran, D. ve Gilchrist, S. (2016). Türkiye'de İ̧̧aret Dili Planlaması ve Türk İşaret Dili'nin Yasal Durumu. Arık, E. (Ed.), Ellerle Konuşmak: Türk Işaret Dili Araştırmaları (ss. 23-50). İstanbul: Koç Üniversitesi Yayınları.

Mills, S. (2004). Discourse. The new critical idiom. New York: Routledge.

Okyayuz, A. Ş. (2019). Görsel-işitsel çeviri ve engelsiz erişim. Ankara: Siyasal Kitabevi.

Oral, A. Z. (2017). Türk işaret dili çevirisi. Ankara: Siyasal Kitabevi.

Padilla, P., Bajo, M.T., Cañas, J.J. ve F. Padilla. (1995). Cognitive processes of memory in simultaneous interpretation. Jorma Tommola (Ed.), Topics in Interpreting Research (ss. 61-71), University of Turku, Centre for Translation and Interpreting.

Pochhacker, F. (2004). Introducing Interpreting Studies. Londra: Routledge

Pöchhacker F. ve Shlesinger M. (Ed.). (2007). Healthcare interpreting: discourse and interaction. Amsterdam \& Philadelphia: John Benjamins Publishing Company.

Reiss, K. ve Vermeer, H. J. (2014). Towards a General Theory of Translational Action. C. Nord (Çev.), Londra ve New https://www.taylorfrancis.com/books/9781315759715.

Resmî Gazete. (2009). Engellilerin Haklarına ilişskin Sözleşme. Son erişim Kasım 2020: http://www.resmigazete. gov.tr/eskiler/2009 /07/20090714-1.htm

Roat C, Crezee I. (2015). Healthcare interpreting. Mikkelson H, Jourdenais R, editors. The Routledge handbook of interpreting. London and New York: Taylor \& Francis Group, s. 236-253.

RTÜK.

(2006)

Televizyon

İzleme

Eğilimleri

Araştırması.

https://www.rtuk.gov.tr/assets/Icerik/AltSiteler/televizyon-izleme-egilimleri-arastirmasi20060053.pdf. 
Covid-19 Pandemi Sürecinde 14 Kuralın Türk İşaret Dili Çevirileri Üzerine Bir İnceleme

RTÜK. (2018). Televizyon İleme Eğilimleri Araştırması - 2018 https://www.rtuk.gov.tr/assets/Icerik/AltSiteler/televizyonizlemeegilimleriarastirmasi20 18.pdf

RTÜK. (2019a). Sağırların, Işitme ve Görme Engellilerin Medya Hizmetlerine Erişiminin iyileştirilmesi Çalıştayı. ttps://www. rtuk.gov.tr/assets/Galeri/Haberler/sagirlarin-isitmevegorme-engellilerin-gorsel-isitsel-medya-hizmetlerineerisiminin-iyilestirilmesi-calistayisonuc-bildirisi.pdf

RTÜK. (2019b). Sağırların, İşitme ve Görme Engellilerin Yayin Hizmetlerine Erişiminin İyileştirilmesine İlişkin Usul ve Esaslar Hakkında Yönetmelik. Resmi Gazete 11 Ekim 2019. https://www.resmigazete.gov.tr/eskiler/2019/10/20191011-15.htm.

Sağırlar Konfederasyonu. (2020). Sağırlar Konfederasyonu Başkanı Orkun Utsukarcı, Koronavirüs Riskine Karşı 14 Kuralı Türk İşaret Diline Çeviri Yaptık. http://www.i3medya.com/sagirlarkonfederasyonu-baskani-orkun-utsukarci-koronavirus-riskine-karsi-14-kurali-turk-isaretdiline-ceviri-yaptik/

Stansfield, C. (2008). A practical guide to sight translation of assessments. Rockville: Second Language Testing, inc.

T.C. Aile, Çalışma ve Sosyal Hizmetler Bakanlığı. (2019). Engelli ve Yaşlı Istatistik Bülteni. https://ailevecalisma.gov.tr/media/9085/buelten-haziran2019-son.pdf

T.C. Sağlık Bakanlığı. (2020). T.C. Sağlık Bakanlığı Covıd-19 Bilgilendirme Sayfası. https://covid19.saglik.gov.tr/

T.C. Sağlık Bakanlığı. (2020). Mar 14, 2020. Sizi ve Türkiye'yi Koronavirüs riskinden koruyacak 14 Kural. https://youtu.be/3Z7MrCQHO-k

Tufan, I. ve Arun, Ö. (2006). Türkiye Özürlüler Araştırması 2002 ikincil Analizi TÜBiTAK PROJE NO: SOBAG-104K077.

http://ozgurarun.com.tr/wpcontent/uploads/2015/08/TufanveArun_TOA.pdf.

Van Dijk, T. (2005). Critical Discourse Analysis. D. Schiffrin, D. Tannen \& H. Hamilton (Ed.), The Handbook of Discourse Analysis (ss. 352-371). Malden: Blackwell Publishing.

WHO. (2020). How to report misinformation online. https://www.who.int/campaigns/connecting-the-world-to-combat-coronavirus/how-toreport-misinformation-online?gclid=CjOKCQiAnb79BRDgARIsAOVbhRrcche6B3V9i5gfPTUBIW1Lhtj2ZU0NPN5aBfWC8m4bQkGSfgYktoaAg-uEALw_wcB 